\title{
Information and Communication Technology in Higher Education
}

Yvonne Buettner \& Charles Duchâteau, Catherine Fulford, Pieter Hogenbirk, Mike Kendall, Raymond Morel, Tom van Weert (Editor)

Hogeschool van Utrecht, University for Professional Development and Applied Science, Cetis, P. O. Box 85029, 3508 AA Utrecht, The Netherlands.

t.vweert@cetis.hvu.nl; http://www.cetis.hvu.nl

Abstract: Various approaches can be identified to the development of Information and Communication Technology (ICT) in Higher Education. These approaches are related to the situation in a particular institution with respect to the growth of ICT. These approaches are: Emerging, applying, integrating and transforming. A Higher Education institution may induce progress in various areas where the ICT-approach will have an impact. These areas are: Vision, Philosophy of learning and pedagogy, Development plans and policies, Facilities and resources, Understanding the curriculum, Professional development of institution staff, Community involvement, Assessment. For each approach a picture is sketched of the impact on the various areas. Separate attention is given to the professional development of teaching staff in each approach.

Key words: approaches to change, areas of change, assessment, community involvement, curriculum, development plans, facilities, formal learning, higher education, Information and Communication Technology, philosophy of learning, professional development, vision

\section{ACKNOWLEDGEMENT}

In the autumn of 2000 a working party of the International Federation for Information Processing (IFIP) produced an updated version of "Information 
and Communication Technologies in Secondary Education, A Curriculum for schools" (Weert \& Tinsley 1994) for UNESCO. This updated version was published under the title "Information and Communication Technology in education, A curriculum for schools and programme of teacher development" by UNESCO in 2002 (Anderson \& Weert 2002 UNESCO, Paris.

There was broad consensus within this working party on the way Information and Communication Technology influences developments in education on all levels. This consensus made it possible to also produce a document specifically aimed at higher education "Information and Communication Technology in Higher Education (http://poe.netlab.csc.villanova.edu/ifip32/).

Members of the IFIP working party were: Yvonne Buettner (Switzerland), Charles Duchâteau (Belgium), Catherine Fulford (USA), Pieter Hogenbirk (The Netherlands), Mike Kendall (United Kingdom), Raymond Morel (Switzerland) and Tom van Weert (The Netherlands)

This document has been edited to fit the format of this book.

\section{APPROACHES TO ICT DEVELOPMENT}

One can identify various approaches to the development of Information and Communication Technology (ICT) in higher education. These approaches are related to the situation in a particular institution across all areas related to the growth of ICT in the institutional system. A matrix has been developed (see Table 1 and Table 2) to help institutions determine their stage of development in various areas. An institution may find itself more in one area of the matrix while being less involved in other areas. The identified approaches and areas of development are in line with international trends of the use of ICT in education.

Each institution must work within the context of its own system to fit choices to what best suits its unique situation and culture. The advancement of technology and the way it is incorporated into a system is a dynamic process. Even within one institution, various units or courses may use different approaches. The approaches are hierarchical with the "emerging" approach as a beginning point, and the "transforming" approach as goal many perceive as the future of education.

\section{Emerging}

This approach is linked with an institution in the beginning stages ICT development. The institution begins to purchase equipment and software. In 
this initial phase, administrators and teaching staff is just starting to explore the possibilities and consequences of adding ICT for institution management and the curriculum. The institution is still firmly grounded in traditional teacher-centred practice. For example, teaching staff lectures and provides content while students listen, take notes, and are assessed on prescribed content. Institution organisation provides discrete time periods for each subject. Learners access to technology is through individual teachers. Curriculum that increases the basic skills and awareness of the uses of ICT assists movement to the next approach (Applying).

\section{Applying}

This approach is linked with an institution in which new understanding of the contribution of ICT to learning has developed. In this phase administrators and teaching staff use ICT for tasks carried out in institution management and in the curriculum. Teachers largely dominate the learning environment. For example, teacher lectures may be supplemented with ICT such as presentation programs and word-processed handouts. Students listen to lectures and add notes to teacher prepared handouts. They use ICT tools to complete required lessons and are assessed on prescribed content. Institution organisation provides discreet time periods for each subject with some flexibility to combine subjects and time periods. Learners access to technology is mainly through computer labs. Up till now ICT has been taught as a separate subject area (ICT-literacy). To move to the next phase (Integrating), the institution chooses to implement an ICT-curriculum that increases the use of ICT in various subject areas with specific tools and software.

\section{Integrating}

This approach is linked with an institution that now has a range of technologies both in laboratories, classrooms, and administrative offices. The institution staff explores new ways in which ICT changes their personal productivity and professional practice. The curriculum begins to merge subject areas to reflect real-world applications. For example, content is provided through multiple sources including resources through the internet. The access of learners to technology enables them to chose projects and ICT tools to learn and demonstrate their knowledge across subject areas. Institution organisation provides overlap and flexibility to combine subjects and time periods. Learners have more choices with regard to learning styles and pathways. They take more responsibility for their own learning and assessment. ICT is taught to selected students as a subject area at the 
professional level. To advance to the next phase, the institution chooses an ICT-curriculum that allows a project-based, ICT enhanced approach

\section{Transforming}

This approach is linked with an institution that has used ICT creatively to rethink and renew institutional organisation. ICT becomes an integral though invisible part of the daily personal productivity and professional practice. The focus of the curriculum is now learner-centred and integrates subject areas in real-world applications. For example, students may work with community leaders to solve local problems by accessing, analysing, reporting, and presenting information with ITC tools. Learners access to technology is broad and unrestricted. They take more responsibility for their own learning and assessment. ICT is taught as subject area at the professional level and incorporated into all vocational areas. The institution has become a centre of learning for the business community.

\section{AREAS OF ICT DEVELOPMENT}

An institution can determine progress in various areas of ICT development. Below general descriptions of those areas are given for all four approaches to the development of ICT in Higher Education.

\section{Vision}

This area refers to the aspirations and goals of both individuals within an institution and the institutional system as a unified whole. As the system advances, the vision should become more unified, be written down, and provide a basis for decision-making. It should help individual members of the learning community visualise the future and act in harmony.

\section{Philosophy of Learning and Pedagogy}

This area refers to ways in which teachers and students interact and the system is managed for learning. These philosophies will necessarily characterise the ways in which ICT is incorporated into the system. A setting that is dominated by the teacher as the provider of content, is a teachercentred philosophy. ICT in this setting is controlled by the teacher as well. A learner-centred philosophy describes a setting where content comes from a 
variety of resources, then projects are chosen and designed by the student. ICT tools and resources are selected to by the student to match the project.

\section{Development Plans and Policies}

This area refers to the detailed steps of how the vision and philosophies are carried out. In this plan, goals and objectives are further defined providing interim and long-term targets. Policies are set, budget is allocated, facilities are dedicated, roles are defined, tasks are delegated, and an evaluation plan is created to define the direction ICT development will take.

\section{Facilities and Resources}

This area refers to the learning environment in which ICT is used. It includes infrastructure such as, electrical wiring, internet access, lighting, air-conditioning, and space. Decisions on inclusion or lack of ergonomic design and choice of furniture impact not only use of ICT, but the health and well-being of users. This area also includes various types of technological devices from computers with peripherals and video equipment to specialised tools like digital microscopes. Resources include various types of software as well as traditional tools like books, videos, and audio-tapes.

\section{Understanding of the Curriculum}

This area refers to the progression of ICT in the curriculum in following various stages of development. First (A.) is an awareness stage in which students become ICT literate with regard to what is available and how it might be used. Second (B.), as students learn basic skills, they begin to apply various ICT tools to their regular tasks and projects. Third (C.), as students become more capable and confident with ICT, they begin to integrate and overlap both subject areas and tools. Last (D.) is the vocational use of ICT in which students are now enabled to tackle larger, more complex, real-world professional applications.

\section{Professional Development of Institution Staff}

This area involves various stages of development that parallel the curriculum for students. The personal productivity and professional practice are enhanced with the use of ICT. First, is an awareness stage (A.) in which teachers and staff become ICT literate with regard to what is available and how it might be used. Second (B.), as teachers and staff learn basic skills, 
they begin to apply various ICT tools to their regular tasks and projects. Third (C.), as teacher and staff become more capable and confident with ICT, they begin to integrate and overlap both subject areas and tools. Last, is a change in professional practice in which teaching staff is now enabled to design lessons to incorporate larger, more complex, real-world projects using ICT tools and resources. As ICT is introduced into systems, there is a tendency to move from discreet skills training to reflective practice and integrative professional development. Budget allocation and provision for release time for professional development seriously impacts the ability of the system to incorporate ITC in a meaningful way.

\section{Community Involvement}

Community involvement may include parents, families, businesses, industry, government agencies, private foundations, social, religious and professional organisations, as well as, other educational institutions such as vocational institutions and universities. Community involvement could be donations of equipment and resources or, may be human resources provided for training and technical assistance. As the community gives to the institutions, the institution can give back in many ways. ICT provides an opportunity for the institution and its students to interact with both local and global communities.

\section{Assessment}

This area includes both assessment of students, as well as overall assessment of the system. These two parts are intricately interwoven. An improvement in one area should predicate an improvement in the other. Means of student assessment should reflect choices in learning pedagogy and the understanding of ICT in the curriculum. For example in the emerging and applying stages of ICT, assessment may be linked to pencil and paper test, while in the in integrating and transforming stages project based portfolios may be more appropriate. Each area of the system as described in the matrix should be assessed to determine its the impact on learning. Assessment should inform practice and support the management of learning. It should allow the system to determine whether outcomes have been met, then, review and revise accordingly. Budget allocations, policies and procedures for ICT should match vision, philosophies, and curriculum choices. 


\section{ICT DEVELOPMENT AT INSTITUTIONAL LEVEL}

Descriptions below provide a picture of what each specific approach to ICT development (emerging, applying, integrating, transforming) may look like in a situation where an institution is at the same level of this approach in all areas (Vision, Learning pedagogy, Development plans and policies, Facilities and resources, Understanding the curriculum, Professional development for institution staff, Community, Assessment).

The rich picture described below, is summed up in a matrix (Table 1 and Table 2).

\section{Emerging Approach}

Please, see Table 1 and Table 2 for a summary.

\section{Emerging: Vision}

The institution's vision of learning and ICT is beginning to develop. The use of ICT is focused on computers under the responsibility of an enthusiastic individual or small group with very specific uses for teaching, or administration based on their own knowledge and expertise. The vision is a pragmatic response with the access to resources and expertise available.

\section{Emerging: Philosophy of Learning and Pedagogy}

The individual teacher is responsible for discrete lessons concentrating on the development of ICT skills and the transmission of subject knowledge. The pedagogy of the enthusiastic individual or small group of teachers is restricted by institutional organisation and limited time periods.

\section{Emerging: Development Plans and Policies}

The development of ICT in the institution is separate from the overall institution development plan and policies regarding curriculum, personnel, professional development, finance, community, teaching, learning and assessment. Teaching staff and students discover for themselves the opportunity to use computers. 


\section{Emerging: Facilities and Resources}

The ICT facilities and resources consists of a few isolated, stand-alone computers and printers in the institution office and a few classrooms. The content available is very limited consisting of generic office type applications and institutional management software with a few games providing reward to some students. Content will be determined by the needs of a few teachers and their teaching.

\section{Emerging: Understanding of the Curriculum}

The ICT teaching is to ensure students are ICT literate. The curriculum is structured to teach students a sound basic understanding of the available software applications. The curriculum is planned and delivered by individual teachers.

\section{Emerging: Professional Development of Institution Staff}

Learning and ICT training will emphasise the need to learn a limited range of software for teaching and administration. Individual members of staff will identify their training needs, generally restricted to technical training. The ICT development plan will identify training separately from other institution training and professional development. ICT training and development is partly funded by the institution and the teacher.

\section{Emerging: Community}

Community involvement is a welcome, although often an unplanned activity. Discrete donations of computers are accepted if and when they are offered. The community is rarely involved in teaching except to solve problems. Guest speakers support learning.

\section{Emerging: Assessment}

Assessment strategies emphasise the limiting nature of equipment and budget on levels of attainment. Paper and pencil testing is widely used due to the limited ICT resources. Assessment allows the teacher to control the pace of learning. Assessment tasks and moderation of levels of attainment is the responsibility of the individual teacher. ICT assessment is independent of other student and institution assessments. 


\section{Applying Approach}

Please, see Table 1 and Table 2 for a summary.

\section{Applying: Vision}

The ICT specialist is responsible for the institution's vision of learning and ICT, with the emphasis on learning about ICT and developing the institution's facilities and resources.

\section{Applying: Philosophy of Learning and Pedagogy}

A teacher centred didactic approach concentrates on the development and transmission of ICT skills and factual knowledge. The pedagogy of ICT specialists enables the teaching and use of ICT as a separate specialist subject.

\section{Applying: Development Plans and Policies}

The ICT specialists concentrating on the acquisition of ICT facilities and resources support part of the institution's curriculum controlling the development of ICT. Responsibility for development of the ICT plan and policies is delegated to the ICT specialist. The plans and policies centralise the use and access to ICT resources, tightly managing access opportunities. Funding is provided for the acquisition of hardware and software in support for a defined part of the institution's curriculum and pedagogy. The plan seeks to automate some existing practice to increase teaching and administration efficiency and effectiveness.

\section{Applying: Facilities and Resources}

There are a number of computer laboratories for ICT specific outcomes with available resources and access managed by the ICT specialist. A limited range of peripherals specific to the ICT curriculum are provided as well as the computers and printers. Internet access is available for a number of the computers. Software is available to teach the ICT curriculum. The applications are used within teaching contexts created by the teacher to provide clear predictable results for the students, ensuring success. The Internet and WWW is used in a controlled way with planned access to known sites to ensure predictable outcomes to lessons. 


\section{Applying: Understanding of the Curriculum}

The ICT teaching will provide opportunities for students to apply their ICT literacy using teacher created and isolated contexts. The curriculum is structured to provide students with opportunities to apply their ICT literacy in other subject areas to acquire specific skills and knowledge.

\section{Applying: Professional Development of Institution Staff}

Skills training will be provided to support the teachers of the ICT curriculum. The training will support the use of individual software applications and learning resources. Training will concentrate on the management of the ICT emphasising personal ICT skill development. The training will tend to be just in time for a specific teaching topic or the arrival of a new piece of software. Internet based training will emphasise the identification of information and direct support for the existing curriculum in a range of subjects.

\section{Applying: Community}

The ICT specialist will be seeking donations and grants to develop the ICT resources and facilities. The ICT skills of the community will be sought in support of the specified curriculum.

\section{Applying: Assessment}

Assessment allows the teacher to report the students' level of ICT literacy and the ability to apply their learning in ICT and other subjects. The teacher shares assessments of students' attainment with other teachers within their subject area to moderate their reporting of standards of attainment. The assessments provide the opportunity for teachers to amend their curriculum. Assessment strategies are the responsibility of individual subject areas. 
Table 1. Areas of ICT-development, first part

\begin{tabular}{|c|c|c|c|c|}
\hline Approach & Vision & $\begin{array}{l}\text { Learning } \\
\text { pedagogy }\end{array}$ & $\begin{array}{l}\text { Development } \\
\text { plans and } \\
\text { policies }\end{array}$ & $\begin{array}{l}\text { Facilities and } \\
\text { resources }\end{array}$ \\
\hline Emerging & $\begin{array}{l}\text { Dominated by } \\
\text { individual } \\
\text { interest } \\
\text { Limited } \\
\text { Pragmatic }\end{array}$ & $\begin{array}{l}\text { Teacher centred } \\
\text { Didactic }\end{array}$ & $\begin{array}{l}\text { Non-existent } \\
\text { Accidental } \\
\text { Restrictive } \\
\text { policies } \\
\text { No planned } \\
\text { funding }\end{array}$ & $\begin{array}{l}\text { Stand-alone } \\
\text { workstations for } \\
\text { administration } \\
\text { Individual } \\
\text { classrooms } \\
\text { Computers and } \\
\text { printers } \\
\text { Word processing } \\
\text { Spreadsheets, } \\
\text { databases, } \\
\text { presentation } \\
\text { Institution } \\
\text { administration } \\
\text { software } \\
\text { Games }\end{array}$ \\
\hline Applying & $\begin{array}{l}\text { Driven by ICT } \\
\text { specialist }\end{array}$ & $\begin{array}{l}\text { Factual } \\
\text { knowledge based } \\
\text { learning } \\
\text { Teacher centred } \\
\text { Didactic } \\
\text { ICT a separate } \\
\text { subject }\end{array}$ & $\begin{array}{l}\text { Limited } \\
\text { ICT resource } \\
\text { lead } \\
\text { Centralized } \\
\text { policies } \\
\text { Hardware and } \\
\text { software funding } \\
\text { Automating } \\
\text { existing } \\
\text { practices }\end{array}$ & $\begin{array}{l}\text { Computer lab or } \\
\text { individual } \\
\text { classrooms for } \\
\text { ICT specific } \\
\text { outcomes } \\
\text { Computers, } \\
\text { printers and } \\
\text { limited } \\
\text { peripherals } \\
\text { Word processing } \\
\text { Spreadsheets, } \\
\text { databases, } \\
\text { presentation } \\
\text { ICT software } \\
\text { Internet access }\end{array}$ \\
\hline Integrating & $\begin{array}{l}\text { Driven by } \\
\text { subject } \\
\text { specialists } \\
\text { Discrete areas }\end{array}$ & $\begin{array}{l}\text { Learner centred } \\
\text { learning } \\
\text { Collaborative }\end{array}$ & $\begin{array}{l}\text { Individual } \\
\text { subject plans } \\
\text { include ICT } \\
\text { Permissive } \\
\text { policies } \\
\text { Broadly based } \\
\text { funding, } \\
\text { including teacher } \\
\text { training }\end{array}$ & $\begin{array}{l}\text { Computer lab } \\
\text { Networked } \\
\text { classrooms, } \\
\text { intranet and } \\
\text { Internet } \\
\text { ICT and learning } \\
\text { resource rich } \\
\text { learning centres } \\
\text { Range of } \\
\text { devices, } \\
\text { including: digital } \\
\text { video and audio, } \\
\text { graphical } \\
\text { calculators, lap }\end{array}$ \\
\hline
\end{tabular}




\begin{tabular}{|c|c|c|c|c|}
\hline Approach & Vision & $\begin{array}{l}\text { Learning } \\
\text { pedagogy }\end{array}$ & $\begin{array}{l}\text { Development } \\
\text { plans and } \\
\text { policies }\end{array}$ & $\begin{array}{l}\text { Facilities and } \\
\text { resources }\end{array}$ \\
\hline Transforming & $\begin{array}{l}\text { Leadership } \\
\text { Acceptance by } \\
\text { entire learning } \\
\text { community } \\
\text { Network centred } \\
\text { community }\end{array}$ & $\begin{array}{l}\text { Critical thinking } \\
\text { and informed } \\
\text { decision making } \\
\text { Whole learner, } \\
\text { multi-sensory, } \\
\text { preferred } \\
\text { learning styles } \\
\text { Collaborative } \\
\text { Experiential }\end{array}$ & $\begin{array}{l}\text { ICT is integral to } \\
\text { overall } \\
\text { institutional } \\
\text { development } \\
\text { plan } \\
\text { All students } \\
\text { All teachers } \\
\text { Inclusive } \\
\text { policies } \\
\text { All aspects of } \\
\text { ICT funding } \\
\text { integral to } \\
\text { overall } \\
\text { institution } \\
\text { budget Integral } \\
\text { professional } \\
\text { development }\end{array}$ & $\begin{array}{l}\text { tops, remote } \\
\text { sensing devices } \\
\text { Video- } \\
\text { conferencing } \\
\text { Word } \\
\text { processing, } \\
\text { spreadsheets, } \\
\text { databases, } \\
\text { presentation } \\
\text { software } \\
\text { Range of subject } \\
\text { orientated } \\
\text { content } \\
\text { Multimedia } \\
\text { authoring, } \\
\text { video/audio } \\
\text { production } \\
\text { Range of subject } \\
\text { specific software } \\
\text { Whole } \\
\text { institution } \\
\text { learning and ICT } \\
\text { infrastructure } \\
\text { and access to a } \\
\text { wide range of } \\
\text { current devices. } \\
\text { Emphasis on a } \\
\text { diverse set of } \\
\text { learning } \\
\text { environments. } \\
\text { All of the above } \\
\text { and } \\
\text { Web based } \\
\text { learning spaces } \\
\text { Brainstorming } \\
\text { Conferencing } \\
\text { and } \\
\text { collaboration } \\
\text { Distance } \\
\text { education } \\
\text { Web courseware } \\
\text { Student self- } \\
\text { management } \\
\text { software }\end{array}$ \\
\hline
\end{tabular}




\section{Integrating Approach}

Please, see Table 1 and Table 2 for a summary.

\section{Integrating: Vision}

The institution's learning and ICT vision is developed and shared by subject specialists seeking to increase the levels of attainment in their subjects, exploring new ways of learning and the management of learning. The vision created belongs to all students, staff and the institution's local and global learning communities.

\section{Integrating: Philosophy of Learning and Pedagogy}

A learner centred approach supporting students' choice of preferred learning styles and learning environments. Students are able to collaborate with other learners, integrating learning across subjects, utilising a wide range of student found resources. The use of ICT to investigate and explore new approaches to learning is accepted.

\section{Integrating: Development Plans and Policies}

The individual subject areas integrate ICT into their plans and policies within the whole institution development plan and policies. The institution's planning processes encourage collaborative approaches to learning and the management of learning by staff and students. The funding of ICT is broadly based and integral to the annual budgetary cycle. The provision of funding covers all aspects of ICT provision, including professional development.

\section{Integrating: Facilities and Resources}

The whole institution is networked to ensure access to multimedia ICT and learning rich resources wherever you are in the institution and out of institution, and via the Intranet and Internet. The computer labs are sufficient in number to allow ready access by students and staff in most subjects across the institution. The content is critically appraised to ensure it matches the requirements of the curriculum supporting a wide range of multi-sensory learning styles. All staff identifies the software and learning resources required. Onsite technical support is provided to ensure the ICT works when required. A wide range of peripheral and remote working devices, including video-conferencing are provided and integrated into the curriculum. Large and small group presentation facilities are readily available. 


\section{Integrating: Understanding the Curriculum}

The curriculum provides the opportunity for students to integrate their ICT literacy into problem solving and projects offering new ways for students to demonstrate their learning. The curriculum seeks to use real context for learning, using institution based and externally available resources. ICT is used as a tutor to support specific learning goals. Staff regularly review the curriculum for opportunities to integrate ICT.

Professional Development of Institution Staff

The emphasis is on the professional development of teachers' subject skills and capabilities to apply ICT in a range of contexts. The provision of institution-based in-service training to support the shared development of collaborative, cross curriculum uses of ICT complements external provision. The institution's programme of professional development has evolved to meet changing needs and new opportunities.

\section{Integrating: Community}

Staff and students make ready use of their local and emerging global learning communities to provide specific assistance for the curriculum making use of the additional opportunities offered through ICT, especially the Internet and video-conferencing. The institution has a regular programme to attract donations and grants to further develop the ICT resources and curriculum

\section{Integrating: Assessment}

The students' assessments are integrated into the whole curriculum, with reports on attainment informing all teachers in planning teaching and learning programmes of study. The students' are responsible for maintaining a personal portfolio, demonstrating their attainment, over time, using ICT facilities and resources to complement paper based records. The assessments inform whole institution curriculum planning and resource allocations.

\section{Transforming Approach}

Please, see Table 1 and Table 2 for a summary. 


\section{Transforming: Vision}

The institution provides leadership to its learning community, providing innovative and creative access and opportunities to learning and the management of learning, maximising the contribution of ICT to realise the institution of tomorrow, today. The institution sees itself as network centred, providing a physical place to learn as well as web based learning spaces, accessible anytime, anywhere by students and staff.

\section{Transforming: Philosophy of Learning and Pedagogy}

The emphasis is upon the whole learner in all aspects of their learning, emphasising critical thinking skills and well-founded decision making. The student is responsible for his or her own learning. Learning is experiential, with learning pathways and learning styles continuously changing to meet learner requirements. The use of ICT to investigate and explore new approaches to learning is expected.

\section{Transforming: Development Plans and Policies}

The institution and learning community has used ICT to creatively rethink and renew the learning environment of students and staff, including the development planning and policy making processes. The plans seek to support continuous change and renewal, striving to provide truly differentiated and individualised curriculum for all students, seeking to maximise achievement. ICT funding is as essential as is the funding for basic utilities such as water and power. Effective, accessible and inclusive ICT enable learning environments are mission critical to all staff, students and learning communities.

\section{Transforming: Facilities and Resources}

A whole institutional learning and ICT infrastructure providing ready access to innovative learning environments and contexts. The facilities and resources are designed and enabled to support continuous change and development of approaches to learning, the management of learning and technology. 


\section{Transforming: Understanding the Curriculum}

The curriculum is enabled by an understanding of the learning needs of every student informed on a continuous basis by management of learning systems. The students' ICT literacy is assumed to readily enable learning within a personalised curriculum. The curriculum normally uses virtual and real world, real-time contexts and modelling. The students are involved with solving real problems.

\section{Transforming: Professional Development of Institution Staff}

The focus in on learning and the management of learning with specific ICT training provided when it is required. The teachers' development is selfmanaged, informed by a well-founded personal vision and plan, supporting the institution's overall vision and the needs of the learners. The teacher accepts he or she is a co-learner, learning with their students. The teachers' are committed to professional development as a continuous critically reflective process.

\section{Transforming: Community}

The community is a natural partner actively involved in all aspects the staff and students learning processes, providing the real world contexts through which learning takes place. The institution is a learning resource for the whole community, offering access to the local and global learning environment with physical visits as well as virtual by the Internet. The institution is as much a part of the community as the community is a part of the institution, the boundaries are indistinct to the observer.

Table 2. Areas of ICT-development, second part

\begin{tabular}{|c|c|c|c|c|}
\hline Approach & $\begin{array}{l}\text { Understanding } \\
\text { of the } \\
\text { curriculum }\end{array}$ & $\begin{array}{l}\text { Professional } \\
\text { development for } \\
\text { institution staff }\end{array}$ & Community & Assessment \\
\hline Emerging & $\begin{array}{l}\text { ICT Literacy } \\
\text { Awareness of } \\
\text { software } \\
\text { Responsibility of } \\
\text { individual } \\
\text { teachers }\end{array}$ & $\begin{array}{l}\text { Individual } \\
\text { interest }\end{array}$ & $\begin{array}{l}\text { Problem driven } \\
\text { Accidental }\end{array}$ & $\begin{array}{l}\text { Equipment based } \\
\text { Budget } \\
\text { orientated } \\
\text { Discrete subjects } \\
\text { Didactic } \\
\text { Paper and pencil } \\
\text { Controlling } \\
\text { Closed tasks } \\
\text { Responsibility of } \\
\text { individual } \\
\text { teacher. }\end{array}$ \\
\hline
\end{tabular}




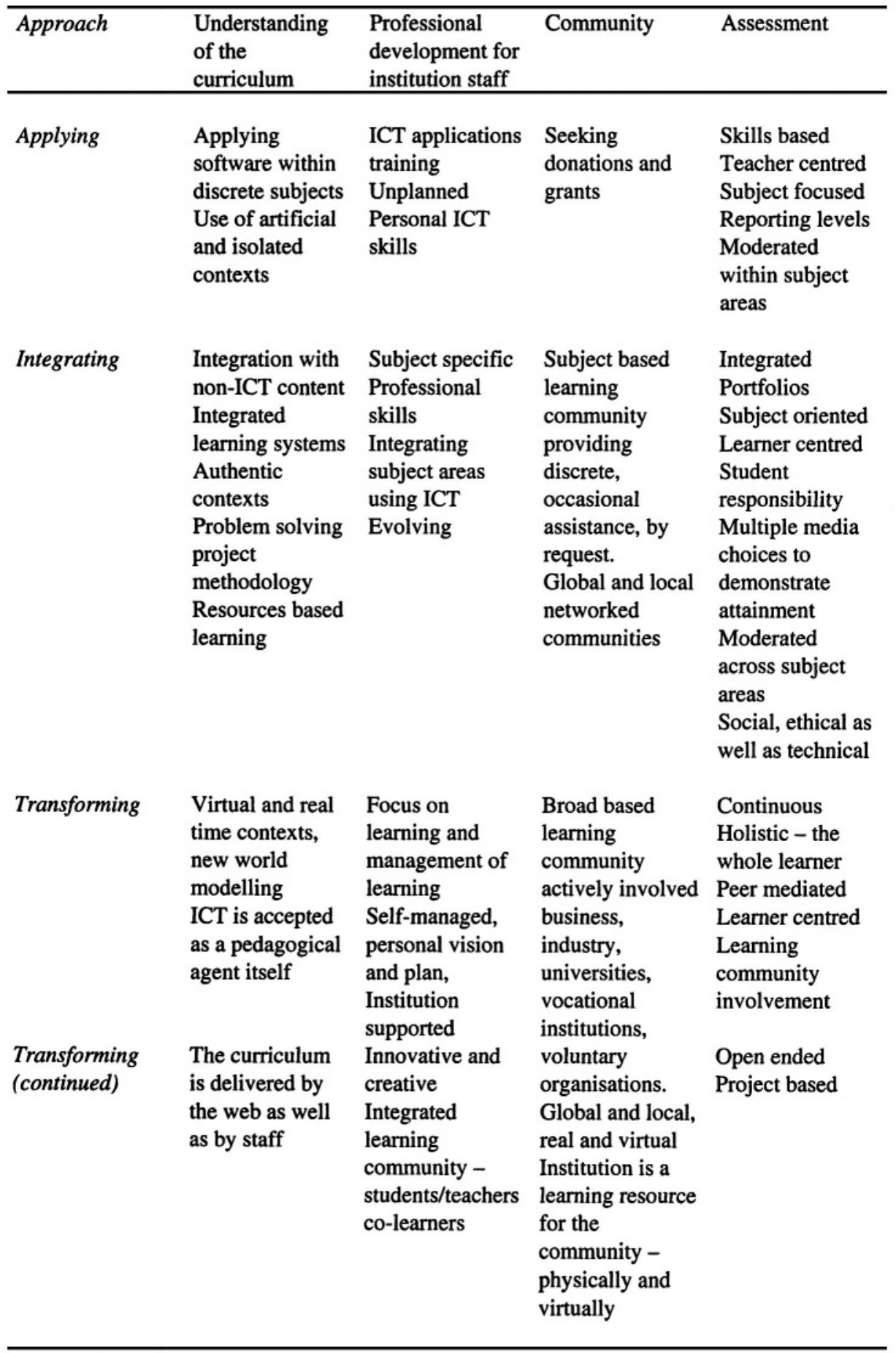




\section{Transforming: Assessment}

The students' are responsible for their own continuous assessment to inform and plan a personal curriculum, matched to their preferred learning styles. The assessments are moderated between students as well as between teachers providing a holistic view of the whole learner across the curriculum. The student maintains a portfolio of all of their work on the network. The students' attainments and preferred learning styles determine the institution's curriculum and policies. Staff and student assessments determine the management of learning.

\section{STAFF DEVELOPMENT}

Teacher training and professional development are essential to establish the use ICT in the professional life of teachers. These are also tied to the approaches that are identified for ICT institutional development:

a) Emerging;

b) Applying;

c) Integrating;

d) Transforming.

\section{Emerging}

In this approach the focus is on the technical functions and uses of ICT and on the need for some knowledge and representation of the impacts of ICT systems as a whole. This approach often involves teachers own personal use of ICT, such as, the use of word processing to prepare worksheets; finding learning resources on CD-ROMs or on the Internet; communicating with friends and family be e-mail.

\section{A. Emerging ICT Skills and Knowledge}

Here teachers are developing their ICT literacy, learning how to apply ICT to a range personal and professional tasks. The emphasis is on training in a range of tools and applications and increasing their awareness of the opportunities for applying ICT to their teaching in the future. 


\section{Applying}

In this approach the teachers use ICT for professional purposes, focused on improving subject teaching to become able to enrich their own ways of teaching with a range of ICT applications. This approach often involves the teachers integrating ICT to teach specific subject skills and knowledge; beginning to change their pedagogy; using ICT to support their own training and professional development.

\section{B Applying ICT to the Teachers' Subject Area}

Teachers have confidence in a number of generic and specialised ICT tools that can applied to the teaching of their subject area. The opportunity to apply ICT in all of their teaching is often limited by the lack of ready access to ICT facilities and resources, hence it is not fully integrated into all lessons for all students.

\section{Integrating}

In this approach ICT integrates in all aspects of professional life to improve the learning and management of learning processes. Integrated ICT supports active and creative teachers, able to propose and manage the learning of students, integrating a range of preferred learning styles and uses of ICT in achieving similar goals. The integrating approach often involves teachers integrating different knowledge and skills from other subjects easily into project based curricula.

C Integrating ICT to improve Learning and the Management of Learning

Teachers are fully integrating ICT in all aspects of their professional life to improve their own learning and the learning of the institution's students. The teacher uses ICT to manage the learning of the students and themselves. They use ICT to assist all students to assess their own learning in achieving specific personal projects. It is natural to collaborate with other teachers to solve problems and to share experiences as they become able to tell and analyse their own experiences (meta-competencies). ICT are not a problem, it is an opportunity.

\section{Supporting Integration by a "Resource Person" for Teachers and Students}

Integration of ICT into a institution needs (as in all other areas) human resources to support users work and needs. Hence, there must be experts or specialist teachers who will spend a great amount of time acting as "resource persons" or ICT co-ordinator. Without this human support, integration will 
not take place, whatever good the other factors are allowing ICT use and integration.

\section{Transforming}

In this approach teachers and other institution staff need not to be convinced of the value of ICT personally and professionally. Teachers and students will expect a continuously changing pedagogy designed to meet their personal learning objectives.

The above approaches are not a necessary hierarchy, they are intended to illustrate the approaches to ICT confidence and competence that many teachers go through, before they begin to transform their practice and the learning of their students. Integration is leading to transformation, the teachers and students will expect a continuously changing pedagogy designed to meet their personal learning objectives, at the same time as the teacher will also be expecting to be supported as they develop their pedagogy. The anxiety of the teacher will no longer be the technology, it will be the understanding of learning processes.

\section{PROGRAMME FOR STAFF DEVELOPMENT}

In (Anderson \& Weert 2002) a programme for staff development is worked out that may also be used for staff development in Higher Education. Here we just give an overview over the programme described there.

\section{A. Emerging ICT Skills and Knowledge}

Here teachers are developing their ICT literacy, learning how to apply ICT to a range personal and professional tasks. The emphasis is on training in a range of tools and applications and increasing their awareness of the opportunities for applying ICT to their teaching in the future.

ICT literacy is not really different for students and for teachers: the basic concepts of understanding and using ICT do contain the same elements. These elements do have a parallel with the (European) Computer Driving License. Of course the actual use of ICT will be different for teachers and for students. Table 3 gives an overview over the relevant elements. More information is to be found in (Anderson \& Weert 2002; Section V.). An ICT literate teacher should be familiar with all the elements of ICT Literacy. 


\begin{tabular}{ll}
\hline A1 & Basic Concepts of ICT \\
A2 & Using the Computer and Managing Files \\
A3 & Word Processing \\
A4 & Working with a Spreadsheet \\
A5 & Working with a Database \\
A6 & Composing Documents and Presentations \\
A7 & Information and Communication \\
A8 & Social and Ethical Issues \\
A9 & Jobs and/with ICT \\
\hline
\end{tabular}

\section{Important points to not forget}

- At this stage, psychological or affective factors are very important. One of the main goals is to decrease the fear about computers, showing the novice they are able to use a computer. Confidence is as important as competence.

- The majority of the professional life of the teacher is at home. Many of the basic skills relevant at this stage are of value for their personal life. The confidence and competence may be learned through autonomous work, using carefully prepared learning materials and, if possible, some distance interactions through appropriate communication tools.

- To support teachers to use ICT in their classes, and as much of their work takes place at home, they have to be encouraged. For example, to buy computers for teachers to use at home, to certificate their new competencies, to provide opportunities make mistakes.

- At this stage many teachers are affected by serious motor-skill difficulties. The very basic motor skills need to be mastered before development of the skills to use ICT tools: this is about confidence and self-esteem.

- Beginners have not only to become able to use ICT tools and environments, but to understand basic principles about architecture, file managing, e-mail transmission. Hence, it is important to provide correct representations about the computing systems and ICT they are expected to use in their institutions, not the theory of what may happen.

\section{B. Applying ICT to the Teachers' Subject Area}

At this stage teachers have confidence in a number of generic and specialised ICT tools that can applied to the teaching of their subject area. The opportunity to apply ICT in all of their teaching is often limited by the 
lack of ready access to ICT facilities and resources, hence it is not fully integrated into all lessons for all students.

There are general competencies, common to all the uses, whatever the subject area. The focus of training and professional develop will need to focus upon these areas as teachers technical confidence and competence grows and they are seeking ways to improve their teaching.

Examples of general competencies:

- Be able to decide why, when, where and how ICT tools will be contribute to the teaching objectives and not provide a distraction; to choose from among a range ICT tools the ones which are the most appropriate to stimulate students learning.

- Be able to manage a class-based learning environment using team work to achieve teaching objectives.

- Be able to decide when whole class or group multimedia presentations will be useful.

- Be able to analyse subject specific multimedia educational software

- Be able to prepare students to find, compare and analyse information from the internet and from other sources specific to the subject area.

- Be able to choose and use appropriate tools to communicate, according to the teachers' own objectives, with colleagues or with their own students.

- Be able to assess communication to use teaching situations to facilitate collaboration.

More information is to be found in (Anderson \& Weert 2002; Section V.).

\section{Important points not to forget}

- At this stage, the emphasis is on the use of generic or specialist tools to improve teaching, in a particular subject area.

- Teachers working together in the same subject area can work together in their institution to share their ideas and the learning resources they have prepared.

- The teacher needs to able to assess the contribution of ICT tools to subject skills and knowledge.

- At this stage teachers need to develop their pedagogy as well as further developing their technical confidence and competence.

- The teacher will still want to control the teaching and learning processes to ensure the lesson will be a success: they will only experiment as their pedagogy develops.

- The teacher is likely to use ICT in lessons that they know they are successful in teaching: this can sometimes lead to frustration, as the 
lesson was not as good. It is good to suggest ICT be used where they know the lesson could be improved, and then if it goes wrong it is not as worrying.

\section{Integrating ICT to improve Learning and the Management of Learning}

At this stage, teachers are fully integrating ICT in all aspects of their professional life to improve their own learning and the learning of the institution's students. The teacher uses ICT to manage the learning of the students and themselves. They use ICT to assist all students to assess their own learning in achieving specific personal projects. It is natural to collaborate with other teachers to solve problems and to share experiences as they become able to tell and analyse their own experiences (metacompetencies). ICT are not a problem, it is an opportunity.

There are general competencies and abilities common to all approaches to the integrating ICT in to learning and the management of learning. The focus of professional development will be on the pedagogic confidence and competence of teachers, building upon their previous training and professional development in applying ICT to teaching. The professional development in this stage will be encouraging teachers to collaborate in developing their curriculum and identifying innovative pedagogy. The opportunity for students and teachers to experiment to identify preferred learning styles and differentiated pathways is encouraged. Integrating ICT across the curriculum to enhance learning and the management of learning leads teachers to an understanding of how to transform their practice and the learning of their students.

General competencies including and building on those at the applying stage:

- To understand why, when, where and how ICT tools will be contribute to the learning objectives; to choose from among a wide range ICT tools the ones which are the most appropriate to stimulate students learning.

- To manage whole institution and classroom based environments, and team work to achieve learning objectives.

- To integrate multimedia presentations into whole class, group or individual teaching and learning to increase access to learning programmes.

- To analyse multimedia learning environments.

- To support students to find, analyse and synthesise information from disparate internet and institution based learning environments. 
- To integrate a range of communication to collaborate with colleagues, with students and other learning communities beyond the institution.

- To use ICT more and more efficiently, continuously taking part in professional development and participating in pedagogical experiments and developments.

\section{Important points not to forget}

One of the roles of a teacher is to help students to transform information, which is everywhere and in enormous amount on the Internet, into knowledge, which only exists in human brains, and into the wisdom to transform their own lives and the communities to which they belong.

As ICT put the stress on teamwork and collaboration for the teachers, teacher training and professional development will be organised not for individuals but for teams, that are local and global, where learners are colearners.

\section{Supporting Integration by a "Resource Person" for Teachers and Students}

Integration of ICT into a institution needs (as in all other areas) human resources to support users work and needs. Hence, there must be experts or specialist teachers who will spend a great amount of time acting as "resource persons" or ICT co-ordinator. Without this human support, integration will not take place, whatever good the other factors are allowing ICT use and integration.

Sometimes this person is also the one who actually teaches informatics at a lower or advanced level. But this task can also be taken care of by another teacher. Also, the more specialised ICT curriculum Units in vocational education will be taught by specialised teachers. We do not fully describe the demands for actually teaching the subject informatics or vocational ICT subject, because that would lead to vast description which also depend very much on legislation and curriculum objectives in the different countries.

Here we will elaborate on the more essential role of the « resource person » or ICT co-ordinator:

- Collaborate with the management and administration;

- Be responsible for the policy towards technical infrastructure;

- Support teachers in integrating ICT to their own practices;

- Give support to team projects;

- Promote ICT uses inside the institution and to facilitate these uses;

- Support some specialised student activities with ICT; 
- Go on with his own professional development.

\section{REFERENCES}

Anderson, Jonathan \& Weert, Tom van (Eds.) (2002) Information and Communication Technology in education, A curriculum for schools and programme of teacher development. UNESCO, Paris.

Weert, Tom van \& David Tinsley (Eds.) (1994) Informatics for Secondary Education, A curriculum for schools. UNESCO, Paris. 